\title{
Emphysematous cholecystitis presenting as gas-forming liver abscess and pneumoperitoneum in a dialysis patient: a case report and review of the literature
}

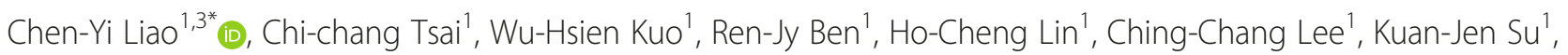
Han-En Wang ${ }^{3}$, Chih-Chiang Wang ${ }^{1}$, I-Hung Chen ${ }^{1}$, Shang-Tao Chien ${ }^{2}$ and Ming-Kai Tsai ${ }^{1}$

\begin{abstract}
Background: Emphysematous cholecystitis is a rare variant of acute cholecystitis with a high mortality rate. The combination of emphysematous cholecystitis, liver abscess and pneumoperitoneum are even rarer. Herein we present a case of emphysematous cholecystitis in a senile diabetic lady who had worsening hemodynamics while undergoing hemodialysis.

Case presentation: A 64-year-old woman with history of type 2 diabetes mellitus and end stage renal disease with regular hemodialysis presented to the emergency department with a 1-day history of sudden onset of lassitude and hypotension during hemodialysis. The result of a computed tomography (CT)-scan revealed air encircling the gallbladder, liver parenchymal and minimal pneumoperitoneal and liver abscess with no cholelithiasis. The patient had received empirical antibiotics with piperacillin-tazobactam $2.25 \mathrm{~g}$ intravenous route every $6 \mathrm{~h}$ for 14 days and cholecystectomy with surgical debridement and lead an uneventful postoperative hospital course. Escherichia coli was demonstrated as well as blood culture and peritoneal fluid culture.

Conclusion: In a senile diabetic and dialysis patient, we should take emphysematous cholecystitis into consideration once vague abdominal pain occurrs. Empirical antibiotic therapy and adequate surgical intervention should take place as soon as possible.
\end{abstract}

Keywords: Emphysematous cholecystitis, Gas-forming liver abscess, Pneumoperitoneum, Dialysis

\section{Background}

Emphysematous cholecystitis (EC) is a rare lifethreatening form of acute cholecystitis representing between 1 and $3 \%$ of acute cholecystitis presenting mainly in male patients aged $50-70$ years, and mostly occurring in patients with diabetes mellitus, immunosuppressed and peripheral vascular disease [1].

EC has been characterized clinically by the imaging with gas in the gallbladder lumen, the gallbladder wall

\footnotetext{
* Correspondence: ericliao0217@gmail.com

'Department of Medicine, Kaohsiung Armed Forces General Hospital, No.2, Zhongzheng 1st Rd, Lingya Dist, Kaohsiung City 802, Taiwan R.O.C

${ }^{3}$ Department of Internal medicine, Division of Nephrology, Tri-service general hospital, National defense Medical center, No.325, Section 2, Cheng-Kung Road, Neihu 114, Taipei, Taiwan R.O.C

Full list of author information is available at the end of the article
}

and adjacent structure, and elsewhere in the biliary tracts in the absence of an abnormal communication with the gastrointestinal tract.

The gas may disseminate to subcutaneous tissue, as well as to the peritoneal and retroperitoneal cavity. The combination of emphysematous cholecystitis, liver abscess and pneumoperitoneum are rarely seen. Dialysis patients rarely develop such complications according to the review of the literature from Pubmed [2].

Subhepatic abscess involved associated with emphysematous cholecystitis is rare [3-5].

Emphysematous cholecystitis occurring in association with a pneumoperitoneum is relatively rare $[6,7]$. A review of the literature from pubmed revealed 18 other 
cases of this combination and this is the first reported case occurring during dialysis.

Herein we present a dialysis case with clinical image composed of emphysematous cholecystitis, liver abscess and pneumoperitoneum.

\section{Case presentation}

A 64-year-old woman with history of type 2 diabetes mellitus and end stage renal disease with regular hemodialysis presented to the emergency department with a 1-day history of sudden onset of lassitude and hypotension during hemodialysis. She complained of fluctuating and persistent dull pain over the epigastric area. The painful sensation could not be relieved by lying down or adopting the decubitus position. She did not have nausea, vomiting, tea color urine, clay-like stool, muscle spasm or focal neurologic signs. She denied contact with animals or travel to foreign countries in recent days. On physical examination, the patient was actually ill and had a body temperature of $37.3^{\circ} \mathrm{C}$, pulse rate of 110 beats per minute, respiratory rate of 40 times per minute and blood pressure of $87 / 65 \mathrm{mmHg}$. The abdomen revealed right upper quadrant tenderness with Murphy's sign and muscular defense of the upper abdomen. In reviewing of the system, no diarrhea, no melena or hematochezia, no dysuria, no hematuria, no flank pain, no periumbilical and flank ecchymosis/petechiae been found. In addition, the laboratory examinations revealed leukocytosis $(12800 / \mathrm{uL})$ with a left shift $(90.4 \%$ neutrophil), elevated C-reactive protein $(44.92 \mathrm{mg} / \mathrm{dL}$ ), liver function impairment (aspartate aminotransferase (AST) of $237 \mathrm{U} / \mathrm{L}$ and alanine aminotransferase (ALT) of $232 \mathrm{U} / \mathrm{L}$ ) and mild jaundice (total bilirubin:1.48 mg/ $\mathrm{dL}$ ). A plain radiography of the chest with the patient in a supine position suggested the presence of a dilated gallbladder with air in the lumen and wall (Fig. 1). The result of a computed tomography (CT)-scan revealed air encircling the gallbladder, liver parenchymal and minimal pneumoperitoneal and liver abscess (Fig. 2a, b, c) with no cholelithiasis. The patient had received empirical antibiotics with piperacillin-tazobactam $2.25 \mathrm{~g}$ intravenous route every $6 \mathrm{~h}$ for 14 days. The blood

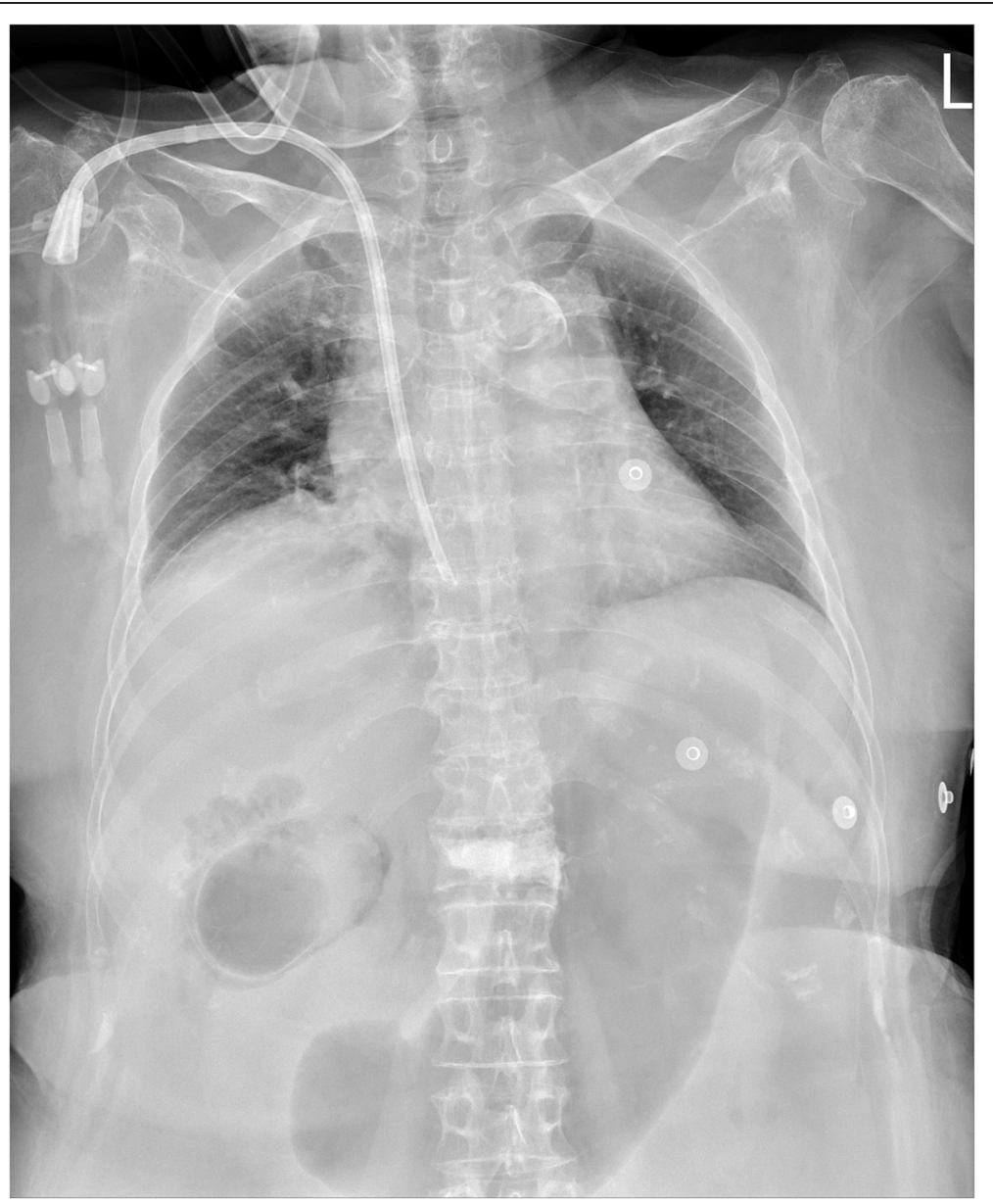

Fig. 1 Plain-film radiography showing air in the lumen and wall of the enlarged gallbladder of a 64-year-old woman with abdomen pain and shock while undergoing hemodialysis (arrows) 


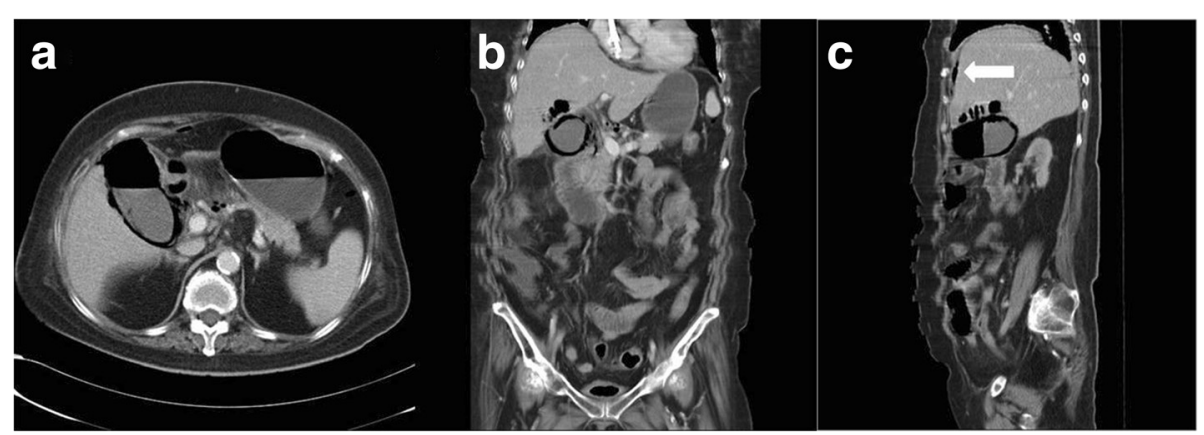

Fig. 2 a Computed tomography revealed air encircled the gall-bladder lumen as well as intramural and pericholecystic air pockets, with findings pathognomonic for emphysematous cholecystitis. b Liver parenchymal destruction by air and partial liver abscess denoted. c Pneumoperitoneum as denoted by white arrow

culture yield Escherichia coli on the 4th admission day. A general surgeon was consulted and cholecystectomy and surgical debridement performed. The postoperative course went smoothly without any complications. The gallbladder was found to be necrotic. The culture of the bile collected during the operation and the peritoneal fluid collected from the pneumoperitoneum were the same as the blood culture yielded Escherichia coli. Pathologic analysis of the resected gallbladder disclosed empyema with extensive transmural necrosis and neutrophils infiltration of the whole organ (Fig. 3). The patient had developed acute delirium status with response to antipsychotic medication and active upper gastrointestinal tract bleeding with response to proton pump inhibitor therapy during the latter hospital course. She successfully recovered without any sequelae after adequate antibiotic treatement.

\section{Discussion}

$\mathrm{EC}$, also known as acute gaseous cholecystitis is pathophysiologically different from acute or chronic cholecystitis. Obstruction of the gallbladder neck secondary to cholelithiasis induces acute and chronic cholecystitis. EC frequently results from thrombosis or occlusion of the cystic artery with ischemia necrosis of the gallbladder wall with subsequent gallbladder necrosis and secondary infection by gas-forming organisms. EC can be subclassified into 3 differente variants including gas in the gallbladder lumen, gallbladder wall and pericholecystic tissues.

The mortality rate in EC is as high as $15 \%$ compared with $4 \%$ in acute choleycystitis [8-11]. The most common symptoms in EC are right upper quadrant abdominal pain. Fever, nausea and vomiting are also the main clinical symptoms of emphysematous cholecystitis.

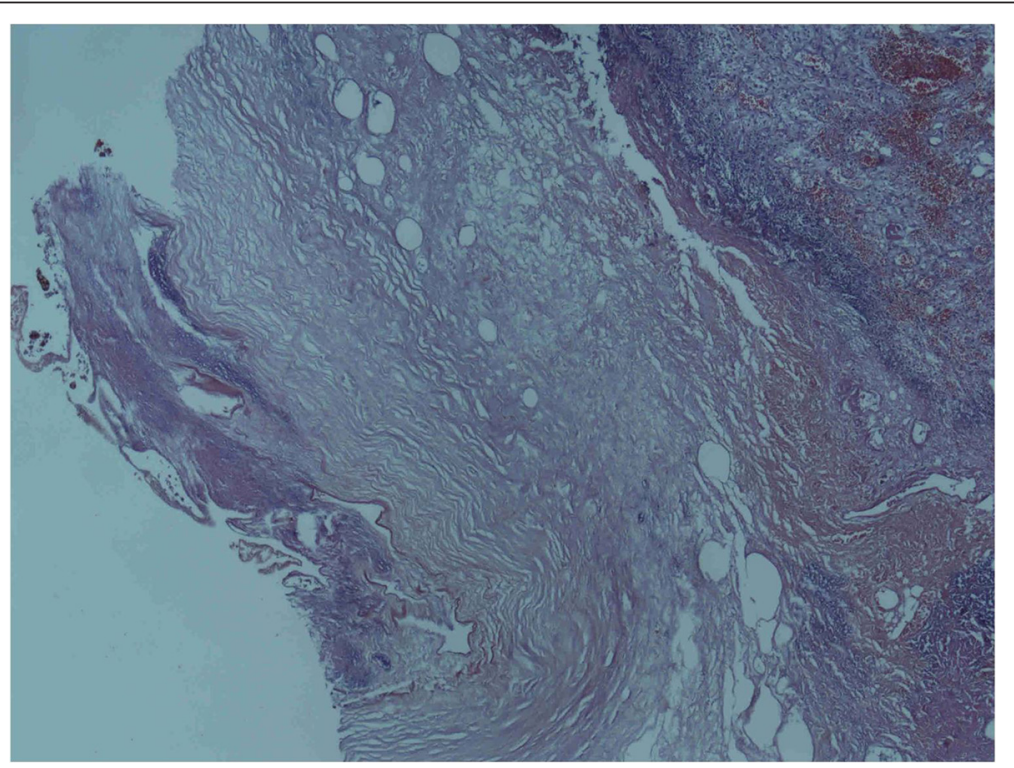

Fig. 3 Pathologic analysis of the resected gallbladder disclosed empyema with extensive transmural necrosis and neutrophils infiltration of the whole organ. Mucosa slough with bacteria colonies been observed (arrow) 
However, the presenting symptoms of EC are sometimes very vague and initially indistinquishable from those of uncomplicated acute cholecystitis, frequently causing a diagnostic dilemma, as in our patient initially masquerading as hypotension while performing hemodialysis. The symptoms may be even trivial in patients with diabetes mellitus and end-stage renal disease $[2,12]$.

We had conduct a systemic review from the series literatures of Pubmed with the linkage between "emphysematous cholecystitis", "diabetes mellitus" and "hemodialysis" which enclosed 23 papers, which include 29 cases of EC, of which 21 cases have the cormobilities of diabetes, one with regular CAPD and the other one received temporary hemodialysis due to acute kidney injury with anuria resulted from hemolytic uremia syndrome. (Table 1) To the best of the author's knowledge, concurrent EC, liver abscess and pneumoperitoneum in a dialysis diabetic patient has not been previously reported (Table 2). Diabetes usually provide an environment for submucosa thrombosis of biliary tract and predispose patients to fulminant infections. The reason for delay in diagnosis probably involves undetermined diabetes neuropathy, which sometimes masks the symptoms of acute abdomen. Hyperglycemia and ischemia environments in diabetic patients can lead to reduced mobility of phagocytes in the areas of infection and further reduce antimicrobial activity, making EC possible. Appropriate control of blood sugar levels can lower the chance of bacterial overgrowth and associated severity of the disease [11].

Chen et al. reported that end-stage renal disease was an independent risk factor for acute cholecystitis. The independent risk factors were older age, higher Charlson's score, atrial fibrillation, severe liver disease, diabetes, and dialysis modality. Haemodialysis patients had a higher risk of acute cholecystitis than PD patients [12].

Another possible postulated mechanism in EC is the fluctuating hemodynamic change during hemodialysis compared with peritoneal dialysis [13]. Hypotension in dialysis patient results from rapid reduction of blood volume owing to ultrafiltration and decrease in extracellular osmolarity during the dialysis session especially in older and diabetic patient with coexisting illnesses, such as cardiovascular diseases, which might contribute to systemic hypoperfusion and further compromise visceral circulation such as the cystic artery which lead to gallbladder ischemia and facilitates the proliferation of gasforming organisms and bacterial translocation in the devitalized tissue with low oxygen saturation. The hypotension episode in our patient can be overlooked due to underlying bacteremia related septic shock may mimic the presentation of dialysis process. Besides, the inflammation and oxidants produced after ischaemia/reperfusion also impair the emptying of the gallbladder, increase the residual volume, and reduce smooth muscle

Table 1 Review of the literature (1955-2015) of emphysematous cholecystitis with association without diabetes mellitus

\begin{tabular}{|c|c|c|c|c|c|c|c|c|}
\hline Number & Age & Gender & Cormobilities & Diabetes & $\begin{array}{l}\mathrm{GB} \\
\text { stone }\end{array}$ & $\begin{array}{l}\text { Operation } \\
\text { /survival }\end{array}$ & $\begin{array}{l}\text { Bacteria source /Concurrent } \\
\text { disease /Causative agents } \\
\text { other than bacteria }\end{array}$ & Author (year) \\
\hline 1 & 54 & M & N/A & - & Yes & Yes $(\mathrm{Ce}) /$ Yes & B/C: C baratii/Liver abscess/- & $\begin{array}{l}\text { Huang et al. (2012) } \\
\text { [5] }\end{array}$ \\
\hline 2 & 80 & $\mathrm{~F}$ & & - & - & PTGBD/- & $\begin{array}{l}\text { Bi/C \& B/C \& abd soft tissue : } \\
\text { Clostridium difficile/myonecrosis/- }\end{array}$ & $\begin{array}{l}\text { Safioleas et al. } \\
\text { (2007) [26] }\end{array}$ \\
\hline 3 & 47 & M & Alcoholism & - & - & Yes $(\mathrm{Ce}) /$ Yes & $\begin{array}{l}\text { Bi/C: Escherichia Coli \& Enterobacter } \\
\text { Femeral tissue culture: Escherichia } \\
\text { Coli, Bacteroids \& Enterobacter/ } \\
\text { myonecrosis -/ - }\end{array}$ & $\begin{array}{l}\text { Safioleas et al. } \\
(2007)[26]\end{array}$ \\
\hline 4 & 72 & M & N/A & - & - & Yes $(L) / Y e s$ & N/A & Ise et al. (2002) [36] \\
\hline 5 & 67 & $\mathrm{~F}$ & - & - & - & Yes $(\mathrm{Ce}) /$ Yes & $\begin{array}{l}\text { B/C, Bi/C negative/Serum: } \\
\text { antibodies against Escherichia coli } \\
\text { O157,adult-onset HUS; liver } \\
\text { abscess/- }\end{array}$ & $\begin{array}{l}\text { Yoshida et al. } \\
\text { (1998) [37] }\end{array}$ \\
\hline 6 & 41 & M & $\begin{array}{l}\text { ESRD secondary to Fabry's with } \\
\text { regular CAPD; status post two } \\
\text { living related donor transplants; } \\
\text { Abdomen vessel calcifications }\end{array}$ & - & - & Yes $(\mathrm{Ce}) /$ Yes & $\begin{array}{l}\text { S/C: Clastridium difficile; P/C: } \\
\text { Clostridium perfringens/recent } \\
\text { massive UGIB/- }\end{array}$ & Mirza et al. (1997) [2] \\
\hline 7 & 64 & M & - & - & - & Yes $(\mathrm{Ce}) /$ Yes & Bi/C: Streptococcus group D-/ - & $\begin{array}{l}\text { Carvalho et al. } \\
\text { (1965) [38] }\end{array}$ \\
\hline 8 & 63 & M & - & - & N/A & $-/$ Yes & N/A & $\begin{array}{l}\text { Tooms et al. (1955) } \\
\text { [39] }\end{array}$ \\
\hline
\end{tabular}

$M$ male, $F$ female, $C A$ cancer, $P A D$ peripheral arterial disease, $C A D$ coronary artery disease, $N / A$ unkown, $-:$ none, $S A H$ subarachnoidal hemorrhage, $E S R D$ end-stage renal disease, HUS hemolytic-uremic syndrome, $O P$ operation, $C A P D$ continous ambulatory peritoneal dialysis, $H G$ hyperglycemia, $F B G$ fasting blood glucose, $G B$ gallbladder, Ce cholecystectomy, Co cholecystostomy, Cd choledochotomy, PTGBD percutaneous transhepatic gallbladder drainage, Lo laparotomy, LC laparoscopy, $B i / C$ bile culture, $B / C$ blood culture, $S / C$ stool culture, $P / C$ peritoneal fluid culture, $A P N$ acute pylonephritis, UGIB upper gastrointestinal tract bleeding 
Table 2 Review of the literature (1955-2015) of emphysematous cholecystitis with association with diabetes mellitus or dialysis

\begin{tabular}{|c|c|c|c|c|c|c|c|c|}
\hline Number & Age & Gender & Cormobilities & Diabetes & GB stone & Operation/survival & $\begin{array}{l}\text { Bacteria source/Concurrent disease/Causative agents } \\
\text { other than bacteria }\end{array}$ & Author (year) \\
\hline \multirow[t]{3}{*}{1} & \multirow[t]{3}{*}{65} & \multirow[t]{3}{*}{$\mathrm{F}$} & CAD & \multirow[t]{3}{*}{ Yes } & \multirow[t]{3}{*}{-} & \multirow{3}{*}{$\begin{array}{l}\text { PTGBD \& liver abscess } \\
\text { drainge/Yes }\end{array}$} & \multirow{3}{*}{$\begin{array}{l}\text { B/C: Clostridium perfringen/Liver abscess, } \\
\text { hemolysis/ - }\end{array}$} & \multirow[t]{3}{*}{ Cochrane. et al. (2015) [4] } \\
\hline & & & PAD & & & & & \\
\hline & & & $\begin{array}{l}\text { Previous acute } \\
\text { pancreatitis }\end{array}$ & & & & & \\
\hline 2 & 85 & M & $C A D$ & Yes & - & Yes/Yes & Bi/C: Clostridium perfringens/-I - & $\begin{array}{l}\text { Mirrakhimov et al. } \\
\text { (2014) [20] }\end{array}$ \\
\hline \multirow[t]{2}{*}{3} & \multirow[t]{2}{*}{77} & \multirow[t]{2}{*}{$\mathrm{F}$} & Gastric CA & \multirow[t]{2}{*}{ Yes } & \multirow[t]{2}{*}{-} & \multirow[t]{2}{*}{ Yes/Yes } & \multirow[t]{2}{*}{-/-/Chemotherapeutic agents } & \multirow[t]{2}{*}{ Kuroda et al. (2013) [21] } \\
\hline & & & Arterial sclerosis & & & & & \\
\hline 4 & 73 & M & $\begin{array}{l}\text { Nephropathy } \\
\text { Schizophrenia }\end{array}$ & Yes & - & Yes/Yes & Bi/C: negative/Escherichia Coli related APN/- & Ogawa et al. (2012) [22] \\
\hline 5 & 11 & M & Obesity & Yes (type1) 1D & - & Yes $($ Lc)/Yes & $\begin{array}{l}\text { Bi/C: Enterococcus P/C: Escherichia Coli/Secondary } \\
\text { appendicitis/ - }\end{array}$ & Pal et al. (2011) [23] \\
\hline 6 & 82 & $\mathrm{~F}$ & $\mathrm{SAH}$ & $\begin{array}{l}\text { HG while admission } \\
\text { (FBG:279mg/dL) }\end{array}$ & - & Yes/Yes & $\begin{array}{l}\text { Bi/C: Clostridium species/Subarachnoidal } \\
\text { hemorrhage/ - }\end{array}$ & Uesaka et al. (2009) [24] \\
\hline 7 & 65 & M & Hypertension & Yes & $\begin{array}{l}\text { multiple GB } \\
\text { stones }\end{array}$ & $\begin{array}{l}\text { Yes (subtotal Ce \& Co) } \\
\text { Yes }\end{array}$ & $\begin{array}{l}\text { Bi/C:toxin A of Clostridium difficile and Escherichia } \\
\text { Coli -/ - }\end{array}$ & $\begin{array}{l}\text { Theodossis et al. (2008) } \\
\text { [25] }\end{array}$ \\
\hline 8 & 87 & $\mathrm{~F}$ & Bedridden state & Yes & - & PTGBD/- & $\begin{array}{l}\mathrm{Bi} / \mathrm{C} \& \mathrm{~B} / \mathrm{C} \& \text { abdomen soft tissue culture: } \\
\text { Clostridium difficile/Renal failure; myonecrosis/- }\end{array}$ & Safioleas et al. (2007) [26] \\
\hline 9 & 32 & M & & Yes & - & Yes (Ce)/No & $\begin{array}{l}\text { Bi/C: Escherichia Coli \& Clostridium Welchii; Femeral } \\
\text { tissue culture: Escherichia Coli/Myonecrosis- }\end{array}$ & Safioleas et al. (2007) [26] \\
\hline 10 & 70 & M & $\begin{array}{l}\text { Heart disease } \\
\text { Hyperlipidemia }\end{array}$ & Yes & $\begin{array}{l}\text { Multiple small GB } \\
\text { stones }\end{array}$ & Yes (Ce)/Yes & $\mathrm{Bi} / \mathrm{C}:$ Clostridium perfringens-/ - & Shresth et al. (2007) [27] \\
\hline 11 & 68 & M & Hypertension CAD & Type 1 & - & Yes (Ce)/Yes & B/C: Clostridium perfringens and Corynebacteria-/ - & $\begin{array}{l}\text { Bernstein et al. (2007) } \\
\text { [28] }\end{array}$ \\
\hline \multirow[t]{3}{*}{12} & \multirow[t]{3}{*}{64} & \multirow[t]{3}{*}{$\mathrm{F}$} & Hypertension & \multirow[t]{3}{*}{ Yes } & \multirow[t]{3}{*}{ Yes } & \multirow[t]{3}{*}{ Yes $(\mathrm{Ce}) /$ Yes } & \multirow[t]{3}{*}{ B/C: Salmonella derby Bi/C: Negative-/ - } & \multirow[t]{3}{*}{ Moanna et al. (2006) [11] } \\
\hline & & & Hypothyroidism & & & & & \\
\hline & & & Anemia & & & & & \\
\hline \multirow[t]{2}{*}{13} & \multirow[t]{2}{*}{62} & \multirow[t]{2}{*}{ M } & Alcoholism & \multirow[t]{2}{*}{ Yes } & \multirow[t]{2}{*}{-} & \multirow[t]{2}{*}{ Yes (Ce)/Yes } & \multirow[t]{2}{*}{ Bi/C: Klebsiella pneumonia-/ - } & \multirow{2}{*}{$\begin{array}{l}\text { Prieto Fernández et al. } \\
\text { (2004) [29] }\end{array}$} \\
\hline & & & Atrial fribrillation & & & & & \\
\hline 14 & 62 & M & Alcoholism & Yes & - & Yes (Ce)/Yes & Bi/C: Klebsiella pneumonia-/ & Prieto Fernández et al. \\
\hline & & & Overweight & & & & - & \\
\hline & & & Atrial fribrillation & & & & & \\
\hline 15 & 42 & M & Recurrent UTI & Yes & Yes & Yes (Ce)/Yes & $\begin{array}{l}\mathrm{U} / \mathrm{C} \& \mathrm{Bi} / \mathrm{C} \text { : Negative /Emphysematous } \\
\text { pyelonephritis/- }\end{array}$ & Bhansali et al. (2004) [30] \\
\hline 16 & 55 & M & Hypertension & Yes & Yes & -Mes & N/A & Chiu et al. (2004) [31] \\
\hline
\end{tabular}


Table 2 Review of the literature (1955-2015) of emphysematous cholecystitis with association with diabetes mellitus or dialysis (Continued)

\begin{tabular}{|c|c|c|c|c|c|c|c|c|}
\hline 17 & 70 & M & N/A & Yes & $\begin{array}{l}\text { Yes (Mirizzi } \\
\text { syndrome) }\end{array}$ & Yes (Ce)/Yes & N/A & Ozkan et al. (2003) [32] \\
\hline \multirow[t]{2}{*}{18} & \multirow[t]{2}{*}{66} & \multirow[t]{2}{*}{$\mathrm{F}$} & Gastric CA post OP & \multirow[t]{2}{*}{ Yes } & \multirow[t]{2}{*}{-} & \multirow{2}{*}{$\begin{array}{l}\text { Yes (PTGBD; Ce and Cd) } \\
\text { Yes }\end{array}$} & \multirow{2}{*}{$\begin{array}{l}\text { Bi/C: Clostridium perfingens \& E. coli/ } \\
\text { pneumobilia/- }\end{array}$} & \multirow[t]{2}{*}{ Ohtani et al. (1996) [33] } \\
\hline & & & Breast CA post OP & & & & & \\
\hline 19 & 77 & M & - & Yes & - & $\mathrm{N} / \mathrm{A}$ & N/A /Liver abscess- & Matsura et al. (1995) [34] \\
\hline 20 & 66 & M & - & Yes & Yes & Yes $(\mathrm{Ce}) /$ Yes & $\mathrm{N} / \mathrm{A}-/-$ & Carvalho et al. (1965) [35] \\
\hline 21 & 68 & M & - & Yes & N/A & $-/ N / A$ & $-1-1-$ & Carvalho et al. (1965) [35] \\
\hline
\end{tabular}


contractility, which may increase the rate of acute cholecystitis in HD patients [14]. Microinflammation in hemodialysis patients also could lead to gut bacterial translocation which further aggravats EC [15]. Chen at al proposed that uremic toxin and increased oxidative stress are both predisposing factors for causing increased gallbladder mucosa inflammation and irritation which further contributed to acute cholecystitis in ESRD patients [12]. The pathogens responsible for the gas formed in EC are usually anaerobes like Clostridium spp, or other microorganisms like Escherichia coli, and Klebsiella spp,Proteus culgaris, Aerobacter aerogenes, Staphylococcus, Streptococcus, and Salmonella derby [11].

Our case demonstrates Escherichia coli in bile culture, blood culture and peritoneal fluid, which suggested that the hemodynamic instability during dialysis favored results from disseminated infection with septic shock. Escherichia coli is a common bacteria present in the gastrointestinal tract, especially in the colon and small bowel. Bactereia tranlocate from duodenal to the biliary tract when local aggressive factors take place, such as peptic ulcer or hemodialysis in our patient [16]. CT scanning of the abdomen is the most sensitive technique for diagnosing emphysematous cholecystitis by presence of gas within the gallbladder wall and lumen. The clinical picture in our case demonstrated liver abscess accompanied with gas retention in the liver parenchyma, gallbladder and biliary tract. Delay in diagnosis of EC could lead to liver abscess formation $[5,15]$. The presence of a concomitant pneumoperitoneum, which may occur following gallbladder perforation, is rarely found. Most patients with a concomitant pneumoperitoneum are an emergent condition that requires emergency exploratory laparotomy, followed by cholecystectomy as in our case. Another method of treatement, involves initial percutaneous cholecystostomy with a strict intravenous antibiotics regimen, followed by subsequent cholecystectomy during second stage. In severely ill patients in particular, percutaneous cholecystostomy with broad spectrum antibiotics may be an alternative choice of treatment.

There are scarce information about the treatment in patients with EC in patients underwent hemodialysis due to end stage renal diseas. Yeh had carried out that laparoscopic cholecystectomy is safe for ESRD patients with gallbladder lesions. Similar blood loss, conversion rate, morbidity, mortality, and hospital stay were achieved by applying laparoscopic cholecystectomy to treat ESRD patients compared with the normal populations [17]. Gunay et al. had proposed that in a patient underwent hemodiaysis with concurrent acute choleycystitis, cholecystectomy may be a better initial choice compared with percutaneous cholecystostomy due to higher success rate and lower morbidity and mortality rate [18]. Gumus et al. suggested that in the management of acute cholecystitis patients with chronic hemodialysis states especially in poor surgical candidate, percutaneous cholecystostomy may be the alternative choice [19].

\section{Conclusions}

In conclusion,emphysematous cholecystitis is a rare form of cholecystitis especially in dialysis patients which could be fatal if delayed in diagnosis and progress to pneumoperitoneal and liver abscess. In a senile diabetic and dialysis patient, we should take emphysematous cholecystitis into consideration once vague abdominal pain and hypotension occurs in a patient underwent hemodialysis. Empirical antibiotic therapy and adequate surgical intervention should take place as soon as possible.

\section{Consent}

Written informed consent was obtained from the patient for publication of this Case report and any accompanying images. A copy of the written consent is available for review by the Editor of this journal.

\section{Abbreviations \\ ALT: alanine aminotransferase; AST: aspartate aminotransferase; CT: computed tomography; EC: emphysematous cholecystitis.}

\section{Competing interests}

The authors declare that they have no competing interests.

\section{Authors' contributions}

CYL participated in writing the manuscript. HEW participated in revision of the manuscript. MKT carried out the study and is the original physician of the patient. RJB participated in infectious survey and interpertate findings of the culture results. WHK participated in providing knowledge of the disease etiology and provide possible differtial diagnosis. HCL, CCL, and KJS collected information of patient and wrote the contents of Clinical course of the manuscript. CCW helped draft the manuscript and revised it. IHC was in charge of the imaging examinations. CCT followed the patient. STC help provide the pathology of the emphysematous gallbladder. All authors read and approved the final manuscript.

\section{Acknowledgements}

We thank to Mr. Steve (language editor) for his involvement in drafting the manuscript and revising it critically for important intellectual content. No obvious source(s) of funding noted.

\section{Author details}

${ }^{1}$ Department of Medicine, Kaohsiung Armed Forces General Hospital, No.2, Zhongzheng 1st Rd, Lingya Dist, Kaohsiung City 802, Taiwan R.O.C.

Department of Pathology, Kaohsiung Armed Forces General Hospital, Kaohsiung, Taiwan R.O.C. ${ }^{3}$ Department of Internal medicine, Division of Nephrology, Tri-service general hospital, National defense Medical center, No.325, Section 2, Cheng-Kung Road, Neihu 114, Taipei, Taiwan R.O.C.

Received: 12 August 2015 Accepted: 19 February 2016

Published online: 01 March 2016

References

1. Choi HS, Lee YS, Park SB, Yoon Y. Simultaneous emphysematous cholecystitis and emphysematous pancreatitis: a case report. Clin Imaging. 2010;34(3):239-41. doi:10.1016/j.clinimag.2007.12.009. 
2. Mirza MM, Wall BM. Emphysematous cholecystitis in a CAPD patient. Perit Dial Int. 1997;17(3):305-7.

3. Kanehiro T, Tsumura H, Ichikawa T, Hino Y, Murakami Y, Sueda T. Patient with perforation caused by emphysematous cholecystitis who showed flare on the skin of the right dorsal lumbar region and intraperitoneal free gas. J Hepatobiliary Pancreat Surg. 2008;15(2):204-8. doi:10.1007/s00534-007-1224-7. Epub 2008 Apr 6

4. Cochrane J, Bland L, Noble M. Intravascular Hemolysis and Septicemia due to Clostridium perfringens Emphysematous Cholecystitis and Hepatic Abscesses. Case Rep Med. 2015;2015:523402. doi:10.1155/2015/52.

5. Huang WC, Lee WS, Chang T, Ou TY, Lam C. Emphysematous cholecystitis complicating liver abscess due to Clostridium baratii infection. J Microbiol Immunol Infect. 2012;45(5):390-2. doi:10.1016/j.jmii.2011.12.007. Epub 2012 May 4.].

6. Modini C, Clementi I, Simonelli L, Antoniozzi A, Assenza M, Ciccarone F, et al. Acute emphysematous cholecystitis as a cause of pneumoperitoneum Chir Ital. 2008;60(2):315-8.

7. Miyahara H, Shida D, Matsunaga H, Takahama Y, Miyamoto S. Emphysematous cholecystitis with massive gas in the abdominal cavity. World J Gastroenterol. 2013;19(4):604-6. doi:10.3748/wjg.v19.14.604.

8. Sunnapwar A, Raut AA, Nagar AM, Katre R. Emphysematous cholecystitis: Imaging findings in nine patients. Indian J Radiol Imaging. 2011;21 (2):142-6. doi:10.4103/0971-3026.82300

9. Kirchhoff P, Müller V, Petrowsky H, Clavien PA. Fatal emphysematous cholecystitis caused by clostridium perfringens. Surgery. 2007;141(3):411-2.

10. Wu JM, Lee CY, Wu YM. Emphysematous cholecystitis. Am J Surg. 2010; 200(4):e53-4. doi:10.1016/j.amjsurg.2010.01.027.

11. Moanna A, Bajaj R, del Rio C. Emphysematous cholecystitis due to Salmonella derby. Lancet Infect Dis. 2006;6(2):118-20.

12. Chen YT, Ou SM, Chao PW, Li SY, Chen TJ, Tsai LW, et al. Acute cholecystitis in end-stage renal disease patients: a nation-wide longitudinal study. Dig Liver Dis. 2013;45(2):142-6. doi:10.1016/.j.dld.2012.08.022. Epub 2012 Sep 26.

13. McIntyre CW. Recurrent circulatory stress: the dark side of dialysis. Semin Dial. 2010;23(5):449-51. doi:10.1111/j.1525-139X.2010.00782.x.

14. Gomez-Pinilla PJ, Camello PJ, Tresguerres JA, Pozo MJ. Tempol protects the gallbladder against ischemia/reperfusion. J Physiol Biochem. 2010;66(2):161-72. doi:10.1007/s13105-010-0021-y. Epub 2010 Jun 23.

15. Zerman G, Bonfiglio M, Borzellino G, Guglielmi A, Tasselli S, Valloncini E, et al. Liver abscess due to acute cholecystitis. Report of five cases. Chir Ital. 2003:55(2):195-8.

16. Shi K, Wang F, Jiang H, Liu H, Wei M, Wang Z, et al. Gut bacterial translocation may aggravate microinflammation in hemodialysis patients. Dig Dis Sci. 2014;59(9):2109-17. doi:10.1007/s10620-014-3202-7. Epub 2014 May 15].

17. Yeh CN, Chen MF, Jan YY. Laparoscopic cholecystectomy for 58 end stage renal disease patients. Surg Endosc. 2005;19(7):915-8. Epub 2005 May 3.

18. Gunay Y, Bircan HY, Emek E, Cevik H, Altaca G, Moray G. The management of acute cholecystitis in chronic hemodialysis patients: percutaneous cholecystostomy versus cholecystectomy. J Gastrointest Surg. 2013;17(2): 319-25. doi:10.1007/s11605-012-2067-3. Epub 2012 Nov 7.

19. Gumus B. Percutaneous cholecystostomy as a first-line therapy in chronic hemodialysis patients with acute cholecystitis with midterm follow-up Cardiovasc Intervent Radiol. 2011;34(2):362-8. doi:10.1007/s00270-010-0025-6. Epub 2010 Nov 18

20. Mirrakhimov AE, Chandra G, Voore P, Khan M, Halytskyy O, Elhassan A, et al. Clostridium perfringens Bacteremia in an 85-Year-Old Diabetic Man. Case Rep Gastroenterol. 2014:8(3):404-7. doi:10.1159/000371540.

21. Kuroda K, Tanaka H, Amano R, Lee T, Ohira M, Muguruma K, et al. A case of emphysematous cholecystitis during the course of chemotherapy for gastric cancer. Gan To Kagaku Ryoho. 2013;40(12):2316-8.

22. Ogawa A, Shikata K, Uchida HA, Shinoura S, Yokomichi N, Ogawa D, et al. Case of emphysematous cholecystitis in a patient with type 2 diabetes mellitus associated with schizophrenia. J Diabetes Investig. 2012;3(6):534-5. doi:10.1111/j.2040-1124.2012.00232.x. Epub 2012 Aug 21.

23. Pal K. Laparoscopy in the management of emphysematous cholecystitis and secondary appendicitis in an 11-year-old child with insulin-dependent diabetes mellitus. See comment in PubMed Commons below. Afr J Paediatr Surg. 2011;8(2):211-4. doi:10.4103/0189-6725.86065.

24. Uesaka K, Seima Y, Tokura M, Shimada Y. A case of emphysematous cholecystitis with cholecystic arterial thromboses and gallbladder infarction. Nihon Shokakibyo Gakkai Zasshi. 2009;106(2):222-7.
25. Papavramidis TS, Michalopoulos A, Papadopoulos VN, Paramythiotis D, Karadimou V, Kokkinakis H, Fahantidis E. Emphysematous cholecystitis: a case report. Published online. 2008. doi: 10.1186/1757-1626-1-73

26. Safioleas M, Stamatakos M, Kanakis M, Sargedi C, Safioleas C, Smirnis A, et al. Soft tissue gas gangrene: a severe complication of emphysematous cholecystitis. Tohoku J Exp Med. 2007;213(4):323-8.

27. Shrestha Y, Trottier S. Images in clinical medicine. Emphysematous cholecystitis. N Engl J Med. 2007;357(12):1238.

28. Bernstein D, Soeffing J, Daoud YJ, Fradin J, Kravet SJ. The obscured gallbladder. Am J Med. 2007;120(8):675-7.

29. Prieto Fernández A, Pardo García A, Docal Cabrera I, Crespo García C, Bernardo Fernández H. Alonso de la Miar P. Epigastralgia in a diabetic patient. Rev Clin Esp. 2004;204(2):91-3.

30. Bhansali A, Bhadada S, Shridhar C, Choudhary S, Khandelwal N. Concurrent emphysematous pyelonephritis and emphysematous cholecystitis in type 2 diabetes. Australas Radiol. 2004;48(3):411-3.

31. Chiu HH, Chen CM, Mo LR. Emphysematous cholecystitis. Am J Surg. 2004; 188(3):325-6.

32. Ozkan U, Akgül E, Okur N. Case report: Mirizzi syndrome in a patient with emphysematous cholecystitis: ultrasonographic and computed tomographic findings. Tani Girisim Radyol. 2003;9(2):220-3.

33. Ohtani Y, Tanaka Y, Tsukui M, Goto K, Moriya H, Tobita K, et al. Acute emphysematous cholecystitis associated with pneumobilia: a case report. Tokai J Exp Clin Med. 1996;21(1):33-6.

34. Matsura T, Kato Y, Murakami R, Watanabe M. A case of gas-containing liver abscess associated with emphysematous change in the gallbladder. Hiroshima J Med Sci. 1995;44(1):7-11.

35. Carvalho HP, Mulero HL, Jackiw NM. Emphysematous cholecystitis in diabetic patients. JAMA. 1965;194(5):561-3.

36. Ise N, Andoh H, Furuya T, Sato T, Yasui O, Yoshioka M, et al. Acute emphysematous cholecystitis preceded by symptoms of ileus: report of a case. Surg Today. 2002;32(2):183-5.

37. Yoshida K, Arakawa M, Ishida S, Sasaki Y. A case of hemolytic uremic syndrome associated with emphysematous cholecystitis and a liver abscess. Tohoku J Exp Med. 1998;185(2):147-55.

38. Carvalho HP, Mulero HL, Jackiw NM. Emphysematous cholecystitis in diabetic patients. JAMA. 1965;194(5):561-3.

39. TOOMS D, BARLOW D. Acute emphysematous cholecystitis. Proc R Soc Med. 1955:48(9):757-9.

\section{Submit your next manuscript to BioMed Central and we will help you at every step:}

- We accept pre-submission inquiries

- Our selector tool helps you to find the most relevant journal

- We provide round the clock customer support

- Convenient online submission

- Thorough peer review

- Inclusion in PubMed and all major indexing services

- Maximum visibility for your research

Submit your manuscript at www.biomedcentral.com/submit
Biomed Central 